\title{
Palliative care in medical education: the students' perception
}

\author{
Cuidados Paliativos na formação médica: percepção dos estudantes
}

\author{
Andrea Augusta Castro' (1) |castro.andreaaugusta@gmail.com \\ Stella Regina Taquette ${ }^{1}$ (D) stella.taquette@gmail.com \\ Caio Assunção Rocha Pereira' (D) caio.assuncaop@gmail.com \\ Natan lório Marques² (D) nataniorio19@gmail.com
}

\begin{abstract}
Introduction: Population aging, longer life expectancy and the increase in the prevalence of chronic diseases have brought new health demands, among them, palliative care (PC). Although present in the clinical routine, this topic has not yet been included in most medical schools in Brazil.

Objective: To know the teaching-learning process in PC according to the perception of medical students from schools that have this subject.

Method: Qualitative method through interviews with 35 medical students from 14 medical schools located in the Northeast, Southeast and South regions of the country.

Results: The reports were classified into three categories: conception of PC, changes perceived after exposure to PC teaching, challenges and successful strategies identified in PC teaching. Students recognize the value of teaching in PC and have a greater understanding of PC approach and its early indication for people with complex chronic conditions. The inclusion of the topic contributed to the overcoming of fears and taboos related to death, providing greater comfort to deal with human suffering, adding emotional skills. The formal education in PC allowed understanding the person in their biopsychosocial and spiritual dimension. They stressed the importance of communication skills to communicate difficult news, symptom management, teamwork and an individualized approach to the person and their family. Although they identify little theoretical-practical integration in the teaching-learning scenario in PC, they report an interest in the topic, and indicated successive experiences as strategies throughout the training, in a humanist axis.
\end{abstract}

Conclusion: PC teaching brings contributions to medical training that go beyond the learning of the subject and reinforces the development of empathy and compassion, recognized as essential in this profession, as well as the relevance of assertiveness in the management of suffering and the comprehensive care of people with advanced diseases.

Keywords: Palliative Care, Medical Education, University graduate.

\section{RESUMO}

Introdução: O envelhecimento populacional, a maior expectativa de vida e o aumento da prevalência de doenças crônicas trouxeram novas demandas em saúde, como os cuidados paliativos (CP). Embora presente no cotidiano clínico, essa temática ainda não foi incluída na maioria das escolas médicas no Brasil.

Objetivo: Este estudo teve como objetivo conhecer o ensino-aprendizagem em CP na percepção do estudante de Medicina de escolas que dispõem dessa disciplina.

Método: Trata-se de estudo qualitativo realizado por meio de entrevistas com 35 estudantes de Medicina de 14 escolas médicas localizadas nas Regiões Nordeste, Sudeste e Sul do país.

Resultado: Os relatos foram classificados em três categorias: concepção sobre CP, transformações percebidas após exposição ao ensino de CP, desafios e estratégias exitosas identificados no ensino de CP. Os estudantes reconhecem o valor do ensino de CP e têm maior compreensão sobre a abordagem em CP e sua indicação precoce às pessoas com condições crônicas complexas. A inserção do tema contribuiu para a superação de medos e tabus ligados à morte, conferindo maior conforto para lidar com o sofrimento humano, agregando competências emocionais. A educação formal em CP possibilitou a compreensão da pessoa na dimensão biopsicossocial e espiritual. Os discentes ressaltaram a importância das habilidades de comunicação de notícias difíceis, do manejo de sintomas, do trabalho em equipe e da abordagem individualizada à pessoa e à família dela. Embora tenham identificado pouca integração teórico-prática no cenário de ensino-aprendizagem de $C P$, os alunos referiram interesse na temática e apontaram como estratégias aproximações sucessivas ao longo da formação, em um eixo humanista.

Conclusão: $O$ ensino de CP traz contribuições à formação médica para além da aprendizagem do tema e reforça o desenvolvimento da empatia e compaixão, reconhecidas como essenciais nessa profissão, assim como a relevância da assertividade no manejo do sofrimento e do cuidado integral de pessoas com doenças avançadas.

Palavras-chave: Cuidados Paliativos, Educação Médica, Graduação.

${ }^{1}$ Universidade do Estado do Rio de Janeiro (UERJ), Rio de Janeiro, Rio de Janeiro, Brazil.

${ }^{2}$ Fundação de Amparo à Pesquisa do Estado do Rio de Janeiro (FAPERJ), Rio de Janeiro, Rio de Janeiro, Brazil

Chief Editor: Rosiane Viana Zuza Diniz.

Associate Editor: Danilo Borges Paulino.

Received on 11/30/2021; Accepted on 12/06/2021.

Evaluated by double blind review process. 


\section{INTRODUCTION}

Population aging and the increase in life expectancy, with the increasing burden of chronic diseases, are considered to have had important effects on the health care network. In 2000 , it was verified that 662,068 people required palliative care, and the estimate for 2040 is that approximately $1,166,279$ people will require this type of assistance in Brazil 1 . The world is on the move and educational systems must prepare and train professionals in line with the current requirements, including core competencies in PC. Given these data, the urgent need for a curriculum that is in line with these population needs is evident. This can be considered a set of articulated pedagogical and administrative action plans, anchored in political-historical realities ${ }^{2}$.

Palliative care (PC) is a therapeutic approach advocated by the World Health Organization (WHO) as the most appropriate for people who are suffering, whether adults or children. Despite the great demand for this type of assistance in health services, little time is devoted to the teaching of PC in the medical curriculum. Evidence indicates benefits in incorporating this approach to people with life-threatening diseases, providing a dignified finitude for the individual and their family ${ }^{3}$. The management of the palliative care approach involves social and ethical issues, such as the reduction of inappropriate and ineffective use of heavy medical interventions and the underutilization of others that would improve the quality of life ${ }^{4}$.

The overall domains in PC comprise the person-and family-centered approach, respect for cultural competence, attention to the patient's physical, psychological, social and spiritual dimensions, as well as dealing with the challenges of clinical and ethical decision-making in PC and the development of communication and integration skills that are essential to teamwork ${ }^{5}$.Although the core competencies in PC are diverse in the curricula, even in countries where palliative medicine has become mandatory in medical schools, three domains predominated: respect to the different patient values in the process of dying, considering the principles and practices of PC, communication skills in the decision-making process at the end of life and management of pain and symptoms ${ }^{6,7}$.

The teaching of PC in Brazil is still incipient and only 44 medical schools include this topic in their curricula, which represents $14 \%$ of the total number of schools in the country ${ }^{8}$. There are few records regarding the contributions that PC teaching brings to medical training from the perspective of students. The present study aims to analyze the perception of medical school students who have PC as a discipline on the teaching-learning process, the achieved benefits, the identified challenges and possible paths as a teaching strategy to guarantee the training of physicians capable of contributing to a dignified life for people suffering from incurable diseases.

\section{METHOD}

Given the specificity of the object under study, i.e., the perception of medical students about the teaching and learning of PC, a qualitative method was used, since it is the most adequate to answer comprehensive questions. Consistent with the study by Castro et al (2021), this is part of a larger investigation on the teaching of PC in Brazil, in which all Higher Education Institutions (HEls) related to medical teaching in Brazil and their curricula were mapped to identify those that include PC teaching and the analysis of how it is being developed according to the perception of coordinators, teachers and students.

In the first stage, a search for the curriculum matrix was carried out in the official Brazilian database of registered schools and in non-governmental websites of medical schools $s^{9,10}$. A total of 315 medical schools were identified in the period from August to December 2018. Subsequently, 315 school curriculum matrices were analyzed on the sites, and only 44 institutions were found to have the Palliative Care discipline in their curriculum matrix. Seven of them were excluded because they had been operating for less than 6 years, and therefore still did not have a graduated class. Contact was made with the 37 remaining schools. Eight did not respond, two refused to participate in the study for several reasons and two were excluded because they reported not teaching the discipline of PC due to the absence of the teachers.

Of the 25 schools eligible for the study, interviews were carried out with students in $14 \mathrm{HEls}$, as eleven of them had no student availability or there were difficulties on the part of the teacher in contacting them. The inclusion criteria adopted for the medical students were the following: attending the school in which the PC discipline was part of the curriculum matrix, having already had the subject and agreeing to participate in the study. To recruit the students applying to the interviews, the HEl that had the discipline in its curriculum matrix was identified. Then, telephone and/or e-mail contact was made with the HEI for the presentation of the research to the coordinator, identification of the teacher responsible for the discipline at the $\mathrm{HEI}$ and random indication of students to participate in the study according to their availability. It should be noted that the interviews took place according to the students' availability and the moment of the school year. The participants were previously informed about the research. The main identified difficulties were matching the curriculum in the field of internship and the meeting to carry out the research. 
The instrument used for data collection was the semistructured interview, which followed a previously tested script containing sociodemographic identification data, open questions about the conception of PC, perception of the teaching-learning process in their school and teaching scenarios and methods used. The dialogue with the students also included facilitating factors and obstacles, the strategies used in the inclusion of PC teaching, and possible pathways for the future of PC teaching.

The interviews were carried out in person or remotely in an environment with privacy and guarantee of confidentiality. All of them were recorded in audio and transcribed in full, with a mode of duration of seventeen minutes. The sample size was defined by the content saturation criterion. The collected data were submitted to the initial analysis during the course of the research and the collection was interrupted when it was understood that no new data had appeared. In total, 35 interviews were carried out with students.

The content analysis was carried out in the thematic modality of the collected data with the support of the WebQDA software for the analysis of qualitative data ${ }^{11}$, having as theoretical basis the core competencies in the field of PC: communication and management of pain and symptoms, the person-centered approach, end-of-life decision-making skills, and the mastery of PC principles and practices, based on international scientific literature on PC teaching. The data were categorized according to the relevance and meanings produced by the interviewees' narratives, aiming to answer the study questions. The following steps were carried out: comprehensive reading of the data; classification of reports according to the categories that emerged; identification of the meanings attributed by the individuals to the raised questions, seeking to understand the internal logic of the group; comparative dialogue with the literature and creation of an interpretive synthesis.

All participants signed the Free and Informed Consent form (FICF). There was no prior knowledge between the researchers and those interviewees, and ethical principles were respected throughout the course of the research.

\section{RESULTS}

Thirty-five interviews were carried out with students, and the majority $(25=71 \%)$ of the HEls were located in the Southeast, the Brazilian region with the highest number of medical schools. Six interviews (17\%) were carried out with students from HEls located the South Region and four (12\%) in the Northeast region. The predominant age group was 20 to 29 years old ( $89 \%$ ) and only four respondents were 30 years old or older. Regarding the students' origin, 18 had graduated from public high schools and 17 from private ones. As for the type of discipline, 28 (80\%) students took compulsory disciplines and seven (20\%) took optional ones. Regarding religion, nine reported being Catholic (26\%), seven (20\%) were Protestant and 10 (29\%) declared they were not linked to any religion (Table 1 ).

As for the characteristics of the curriculum and PC discipline according to the type of school, it was observed that the subject is a compulsory one in most of them, lasting a semester and with a workload of between 40 and 100 hours. The difference related to the administrative nature of the school was the type of curriculum, which is predominantly modular in public schools and traditional in private schools (Table 2).

Table 1. Distribution of sociodemographic data of the students interviewed according to the administrative nature of the schools (public or private).

\begin{tabular}{|c|c|c|c|c|}
\hline & \multicolumn{2}{|c|}{ Public schools } & \multicolumn{2}{|c|}{ Private Schools } \\
\hline & $\mathbf{N}$ & $\%$ & $\mathbf{N}$ & $\%$ \\
\hline \multicolumn{5}{|l|}{ Gender } \\
\hline Male & 9 & 50 & 9 & 53 \\
\hline Female & 9 & 50 & 8 & 47 \\
\hline Total & 18 & 100 & 17 & 100 \\
\hline \multicolumn{5}{|l|}{ Age Group } \\
\hline 20 to 24 & 13 & 72 & 10 & 59 \\
\hline 25 to 29 & 3 & 17 & 5 & 29 \\
\hline 30 to 34 & 1 & 5.5 & 2 & 12 \\
\hline 35 to 50 & 1 & 5.5 & 0 & 0 \\
\hline Total & 18 & 100 & 17 & 100 \\
\hline \multicolumn{5}{|l|}{ Religion } \\
\hline Buddhism & 2 & 11 & 0 & 0 \\
\hline Catholic & 5 & 28 & 4 & 24 \\
\hline Christian & 2 & 11 & 1 & 5.5 \\
\hline Spiritist & 0 & 0 & 4 & 24 \\
\hline Protestant & 0 & 0 & 7 & 41 \\
\hline No religion & 9 & 50 & 1 & 5.5 \\
\hline Total & 18 & 100 & 17 & 100 \\
\hline \multicolumn{5}{|l|}{ Region } \\
\hline Southeast & 10 & 55 & 15 & 88 \\
\hline Northeast & 5 & 28 & 0 & 0 \\
\hline South & 3 & 17 & 2 & 12 \\
\hline Total & 18 & 100 & 17 & 100 \\
\hline \multicolumn{5}{|c|}{ Type of discipline } \\
\hline Compulsory & 13 & 72 & 15 & 88 \\
\hline Optional & 5 & 28 & 2 & 12 \\
\hline Total & 18 & 100 & 17 & 100 \\
\hline
\end{tabular}

Source: created by the authors. 
Table 2. Distribution of curriculum and PC discipline characteristics according to the administrative nature of the school.

\begin{tabular}{ccccc}
\hline & \multicolumn{2}{c}{ Public } & \multicolumn{2}{c}{ Private } \\
\cline { 2 - 5 } & $\mathrm{N}$ & $\%$ & $\mathrm{~N}$ & $\%$ \\
\hline $\begin{array}{c}\text { Type of curriculum } \\
\text { Traditional }\end{array}$ & 1 & 17 & 5 & 62.5 \\
Modular & 5 & 83 & 3 & 37.5 \\
Total & 6 & 100 & 8 & 100 \\
\hline Type of subject & & & & \\
Compulsory & 4 & 67 & 6 & 75 \\
Optional & 2 & 33 & 2 & 25 \\
Total & 6 & 100 & 8 & 100 \\
\hline Course semester & & & & \\
$1^{\text {st }}$ sem & 5 & 83 & 6 & 75 \\
$2^{\text {nd }}$ sem & 1 & 17 & 1 & 12.5 \\
$3^{\text {rd }}$ sem & 0 & 0 & 1 & 12.5 \\
Total & 6 & 100 & 8 & 100 \\
\hline Workload $(\mathrm{h})$ & & & & \\
$<40 \mathrm{~h}$ & 2 & 33 & 0 & 0 \\
$>40$ and $<100 \mathrm{~h}$ & 1 & 17 & 5 & 62.5 \\
$>$ 100 $\mathrm{h}$ & 3 & 50 & 3 & 37.5 \\
Total & 6 & 100 & 8 & 100 \\
\hline Soure: created by the & & & & \\
\hline
\end{tabular}

Source: created by the authors.

After reading the interviews, the data were classified into three categories: students' conception of PC; perceived transformations after exposure to $P C$ teaching, and challenges and coping strategies identified in PC teaching.

The interviewed group consisted mostly of young adults, where the regional characteristics, the interviewee's gender and religion and the administrative nature of the school did not represent outstanding differences in the students' statements regarding the study object and for this reason, the data were classified together.

\section{Conception about palliative care}

This category includes the student's perception on PC, its meaning and the teaching-learning process, as well as the importance given to the topic for their education. Convergence was observed in the students' narratives, both in the HEls in which the subject was compulsory and in those where it was optional. They express that this discipline should be offered to all students in the healthcare area, regardless of the specialty they will follow, since it is part of the clinical routine of the profession.
"I see that it is very important, because we increasingly have diseases that need this modality, (...) I think this first contact is important." (male, 22 years old, Southeast)

"...not restricted to a specialty in itself, (...) that is something integrated to the clinic." (male, 23 years old, Northeast)

The students' understanding of the care modality in PC reveals a broader scope in palliation and an earlier indication, contrary to what is usually restricted to terminally-ill patients, as exemplified in the speech below:

"After having the course, my view has been expanded to understand that within any diagnosis of a chronic disease, I can implement this care." (male, 21 years old, Northeast)

The interviewees reported changes in the representation and symbolic value of topics related to the process of dying and death, after exposure to PC teaching.

"...it is a taboo, there are people who cannot deal with their own death." (male, 21 years old, Southeast)

According to the students, the meaning of PC can be interpreted in several ways and must be adapted to each patient. However, an open construction in the physician-patient relationship is important, which requires expanded listening, an acquisition of skills by the students to know how to relieve, to take better care, as this changes the person's life, and these are fundamental principles of Medicine.

"I think it's very important, because it is medical care, even though there is no cure for that disease, but we have to relieve the suffering of others. I think the art of healing is the same as the art of relieving, people don't need to suffer at the end of their lives."(male, 36 years old, Northeast)

Based on the dialogue with the students, regardless of their religious beliefs, the importance of spirituality was emphasized, and of discussing the meaning of the experience of suffering.

"...to understand the dimensions of suffering and how they are private(..) and how spirituality is different from religion." (female, 24 years old, Southeast)

Another information obtained from the students' narratives refers to the opportunities that students had to resignify their experiences with groups such as the elderly and children with complex chronic conditions. These were used to reveal that the PC approach can also be offered to patients in the pediatric and youth groups, according to the student's narrative below: 
"...it did not cross my mind (...), that there were children, adolescents, young people, they were not the profile I imagined." (male, 22 years old, Southeast)

In summary, the students' narratives showed that the conception of PC, previously restricted and indicated to the population in the end-of-life phase, after the teaching-learning experience was extended to other groups and with an early inclusion. This change in the perception of PC makes it possible for students to deal with difficult, necessary and inevitable topics in medical education, such as the process of dying and death.

\section{Changes perceived after exposure to PC teaching}

PC teaching increased the students' understanding of the person as a whole, by shifting the focus from the disease to the individual and working on the humanistic potential, helping to develop compassion. As the student reveals:

"I think PC is necessary in the physicians' training because it makes it possible to see the patient in a different way(..), a more humane way of dealing with the illness of others." (male, 21 years old, South)

One of the most important aspects that were perceived refers to the incorporation of the understanding of the human being involving the biopsychosocial dimension, as reported by the student:

"...disease is in the human being, atherosclerosis does not come walking, depression does not come, in a person with atherosclerosis, with depression." (male, 22 years old, Southeast)

It was clear in the students' narratives that the changes occur from a significant learning in PC, which allowed them to perceive the needs of the patient and their family. As the student reports:

"... to have sensitivity and identify what the patient needs, in addition to technical knowledge, of the disease that the patient has, (..), one must have humanistic competence to approach the patient and the family!" (female, 21 years old, South)

The PC discipline provided significant learning of the bioethics principles, a more humanized view of medicine, according to the speakers. Moreover, an assertive attitude of embracement, of bringing up an environment of attention, affection and love, because there are limits to healing, but there are no limits to caring. According to the students' narrative, it is always possible to "try to offer something, somehow" (male, 29 years old, Northeast).

The power of teaching in the development of attitudes and knowledge to minimize suffering is valued, as reported by the student:
"Talking about empathy yes, but living compassion, I understand that PC needs to be assertive." (male, 23 years old, Southeast)

It can be verified that the students realized that there were significant personal transformations after the teachinglearning process in PC. They pointed to the importance of PC teaching in personal development. Going through challenging experiences brought them greater security and confidence in their professional performance, as it strengthens emotional skills and provides better conditions to work in difficult situations, as the student reveals:

\section{"...it gave me greater protection, so that I protect myself, a balance between the professional and the emotional, and seeing the human being in a holistic way, being born-living-dying, in an integrated way." (female, 29 years old, Southeast)}

One of the most significant aspects highlighted by the students was the possibility of overcoming prejudices commonly observed in medical practice, which reveal the lack of interest and inhumanity in dealing with patients with no curative possibility. One of the interviewees exemplifies:

"...when we hear people talking, and sometimes even in a derogatory way, send them to the palliatives because there is nothing else to do, and that was the view we had before".( female, 22 years old, Southeast)

\section{Challenges and coping strategies in PC teaching}

The interviewees' speeches reflected a common scenario in health practices, the difficulty in dealing with death and the end of life, which lead the professionals to deny and distance themselves from situations in which they are faced with this problem. On the other hand, issues related to PC were evidenced as being of great interest to the interviewees, perhaps precisely because of the lack of discussion on these topics during the medical course, and the explicit denial in the previous category. Doubts about the limits of interventionist measures, about what to offer in the face of little or no curative proposal, were repeated in the narratives. To deal with these demands, the strategy of talking and discussing topics involving dying and death was suggested. As the student points out:

"To demystify the taboos, every class constitutes limitless learning, everyone should have PC." (female, 31 years old, Southeast)

Another challenge observed was the dichotomy between theory and practice. The students describe a lack of experience in PC in professional practice environments, and also assess a discrepancy between what is seen in theory and what is observed in practice, as revealed by the student: 
"... can't do it, the right thing can't be applied". (female, 24 years old, South).

The appreciation of practical scenarios and the use of the health care network with a view to PC allow the development of the family approach, taking care of those who care. As reported by the student:

"I thought it was just the patient, I forgot about the family, it is important to take care of those who take care." (male, 21 years old, South)

Students report that, with successive experiences, they feel more comfortable talking with the patient, extracting the history, and thinking about possible actions aimed at the person.

"... what PC can bring is this, a more attentive listening to patient issues, the development of skills by the physician" (female, 22 years old, Southeast)

Thestudents reported difficulties with corecompetencies, including: communication, symptom management, opioid use, teamwork, psychosocial and spiritual approach in the cultural context. However, one of the biggest challenges is related to the communication of bad news, as disclosed:

"...a taboo saying that someone is going to die. Just by breaking the news changes everything, we did not learn that in medical school. Unfortunately." (female, 24 years old, Southeast)

One of the suggested paths would be to focus on the patient and not on the disease, based on a stronger humanist axis in the curriculum, integrating the topics during training.

The students report that the interest in the topic is increasing and schools must rethink the curriculum. They indicate the need to include the PC discipline in undergraduate medical school, as well as in other undergraduate courses in the health area. As the interviewee points out:

"...it should be a mandatory discipline in all schools, (...) and not just in the medical course". (male, 22 years old, Southeast)

The students' narratives identified taboos and prejudices related to the topic of death and the dying process, the core competencies in PC, the necessary scenarios for learning, and the PC teaching model as the main challenges, and the students pointed out pathways and strategies that will allow the inclusion of PC teaching.

\section{DISCUSSION}

The students' perception of PC is in line with the expanded concept of the topic as an approach that improves the quality of life ${ }^{12}$. The international entities in PC reinforce characteristics such as active and comprehensive care through the prevention of suffering, which means early identification, not only offered at the end of life, and the management of pain and other physical, psychosocial and spiritual problems ${ }^{13,14}$. Therefore, the pediatric and youth population with complex chronic diseases, which are now reaching adolescence and adulthood, can benefit from the PC approach. The teaching of PC allows the expansion of resources in the management of suffering, in any medical specialty ${ }^{15,16}$.

The reflections pointed out by the students highlight that PC education should be offered to all students, which is corroborated by international entities, by recommending the training of professionals in undergraduate school, regardless of the future physician's area of specialization, since the approach of core competencies in PC is applied in different scenarios and levels of care $^{17,18}$.

According to the students' narratives, the acquisition of general skills is favored by the systematized PC teaching and minimizes fears and prejudices associated with the topic of death. Learning about resources to alleviate suffering reduces the feeling of having nothing to do and can be a pathway brought on by the PC approach. Moreover, the importance of spirituality, regardless of one's religion, in the management of suffering was emphasized, corroborated by the study of Lucchetti et al ${ }^{19}$.

According to Ellman et al, the acquisition of core competencies in PC favors a closer contact of students with patients with advanced diseases and their families ${ }^{20}$. According to Gibbins et $\mathrm{al}^{21}$, the inclusion of PC teaching in undergraduate courses allows the student to develop skills that will improve their professional performance in overall patient care.

The incorporation of palliative care teaching in undergraduate courses is an essential premise for good practices in health care, according to Freitas et $\mathrm{al}^{22}$. There is a worldwide concern in ensuring that health professionals receive education and training in $P C$ in training courses and integrated into the health system ${ }^{23}$.

Regarding the transformations that occurred after PC teaching and learning, the understanding of care stands out, focusing not only on the disease, but on the person with a disease in a given context, comprising the biopsychosocial dimensions. This perception is in accordance with the National Curriculum Guidelines, which reaffirms the importance of PC teaching as a potentiator of a humanist, critical and thoughtful graduated student ${ }^{24}$.

The undergraduate student's experiences in situations that involve the finitude of life and the care of people with advanced diseases accompanied by the discussion on this topic in the PC teaching-learning process is very appropriate and productive in the sense of working on the development of 
emotional and communication competencies, comprehensive care and considerations about the meaning of life. Studies corroborate that PC teaching is a moment of transformation, for both the caregiver and the one who is cared for ${ }^{25,26}$. According to Schulz et $\mathrm{al}^{27}$, PC teaching allows changes in values and attitudes, from the alternation of didactic learning followed by self-reflection on experiences. On the other hand, according to studies by Spalding et $\mathrm{al}^{28}$, an improvement in communication skills, teamwork and family support is observed in the places where PC teaching was provided, in addition to symptom management.

The challenges for the implementation of PC teaching pointed out in this research corroborate the study by Gibbins et $\mathrm{al}^{29}$. They refer to the lack of integration in the assistance network scenarios, teamwork and also the absence of qualified staff in PC. The students reinforced the importance of having teaching-assistance scenarios with teaching opportunities in real situations at different levels of care. These points positively dialogue with the precepts established by the National Humanization Policy of the Brazilian Unified Health System (SUS), which for years has highlighted the need to think about the space of care, the autonomy of the patient and their rights, but which in fact have not been formally included in medical training and not even as a care modality ${ }^{30,31,32}$.

The still hegemonic teaching model is the biomedical one, prioritizing the disease-centered view, which was criticized by the interviewees, since attention should focus on the patient, and not on the disease. The PC teaching might be a driving force for the integrality mode ${ }^{33,34}$.

The limitations of the present study are highlighted, as it was restricted to a portion of medical school students who have PC training. However, it brings contributions and subsidies to education and health policies by emphasizing the relevance and need for PC teaching beyond the learning of the subject, reinforcing the development of empathy and compassion, acknowledged as essential in this profession.

\section{FINAL CONSIDERATIONS}

The knowledge produced in this study indicates that the teaching-learning process regarding the process of dying and death allows medical students to be more assertive when dealing with people with severe illnesses. A formal PC education provides the acquisition of emotional skills to deal with human suffering. For that purpose, the importance of practical scenarios and the integration of learning in successive experiences, in a humanist axis, was highlighted. Therefore, PC teaching-learning contributes to the training of physicians who are more competent when dealing with people with incurable diseases, offering them more dignity at this stage of their lives.
The demographic and epidemiological changes, together with the incorporation of technology in health and aspects of health care bring needs to medical education. Death as a natural and inexorable event in the course of life must be a present topic, in a systematic and interdisciplinary way, during professional training. It is not just about including one more subject in the curriculum, but the construction of a longitudinal axis that works with the core principles of PC throughout the future physician's training.

Physicians face many uncertainties and expectations during care. Patients yearn for healing, but when that is impossible in a time of suffering, the PC approach offers a dignified and embracement approach. A physician-patient relationship must be based on the Hippocratic principles: "to cure sometimes, to relieve often, to comfort always". This is the heart of care.

\section{AUTHORS' CONTRIBUTION}

Andrea Augusta Castro and Stella Regina Taquette equally participated in the conception and design of the study, collection, analysis and interpretation of the research data and the writing of the manuscript. Caio Assunção Rocha Pereira participated in the data collection and organization. Natan lório Marques participated in data acquisition and organization.

\section{CONFLICTS OF INTEREST}

The authors declare no conflicts of interest.

\section{SOURCES OF FUNDING}

This study was funded by FAPERJ, submitted to "Edital Faperj 12/2018- Programa apoio as Universidades Estaduais-UERJ, UENF and ENZO".

\section{REFERENCES}

1. Santos CL, Campos L, Barros N, Serafim JA, Klug, D, Cruz RP. Palliative care in Brasil: present and future. Rev Assoc Med Bras. 2019;65(6):796-800. doi: 10.1590/1806-9282.65.6.796.

2. Jonnart P, Ettayeb M, Defise R. Currículos e competências. Porto Alegre: Artmed, 2010.

3. Chiu N, Cheon P, Lutz S, Lao N, Pulenzas N, Chiu L, et al. Inadequacy of palliative training in the medical school curriculum. J Cancer Educ. 2015;30(4):749-53. doi: 10.1007/s13187-014-0762-3.

4. Victor GHGG. Cuidados paliativos no mundo. Rev Bras Cancerol 2016;62(3):267-70 [acesso em 19 de mar de 2019]. Disponível em: https:// rbc.inca.gov.br/revista/index.php/revista/article/view/343.

5. Gamondi C, Larke P, Payne S. Core competencies in palliative care: an EAPC White Paper on palliative care education - part 2. Eur J Palliat Care. 2013;20(3):140-5 [acesso em 17 de mar de 2020]. Disponível em: http://www.haywardpublishing.co.uk/_year_search_review. aspx? JID=4\&Year=2013\&Edition $=474$.

6. SchiessIC, Walshe M, Wildfeuer S, Larkin P,Voltz R, Juenger J. Undergraduate curricula in palliative medicine: a systematic analysis based on the palliative education assessment tool. J Palliat Med. 2013;16(1):20-30. doi: 10.1089/jpm.2012.0281. 
7. Schaefer KG, Chittenden EH, Sullivan AM, Periyakoil VS, Morrison LJ, Carey EC, et al. Raising the bar for the care of seriously ill patients: results of a national survey to define essential palliative care competencies for medical students and residents. Acad Med. 2014;89(7):1024-31. doi: 10.1097/ACM.0000000000000271.

8. Castro AA, Taquette SR, Marques NI. Cuidados paliativos: inserção do ensino nas escolas médicas do Brasil. Rev Bras Educ Med. 2021;45 (2): e056. doi: 10.1590/1981-5271v45.2-20200162.

9. Brasil. Sistema e-MEC. Instituições de educação superior e cursos aadastrados. Brasília: MEC; 2017 [acesso em 17 dez 2017]. Disponível em: http://emec.mec.gov.br/.

10. Nassif ACN. Escolas médicas do Brasil. São Paulo: Nassif; 2018 [acesso em 19 ago 2018]. Disponível em: http://www.escolasmedicas.com.br/estat.php.

11. Costa AP, Amado J. Análise de conteúdo suportada por software. AveiroPortugal: Ludomedia; 2018.

12. Worldwide Hospice Palliative Care Alliance. Global atlas of palliative care. 2nd ed. London: WHPCA [acesso em 30 jun 2021]. Disponível em: http:// www.thewhpca.org.

13. Organization World Health. National cancer control programmes: policies and managerial guidelines. 2nd ed. Geneva:WHO; 2002 [acesso em 12 jun 2021]. Disponível em: https://www.who.int/cancer/media/en/408.pdf.

14. Organization World Health. Global atlas of palliative care at the end-of-life. Geneva:WHO; 2014 [acesso em 2 dez 2014]. Disponível em: http://www. who.int/nmh/Global_Atlas_of_Palliative_Care.pdf.

15. Duarte JG, Gomes SC, Pinto MT, Gomes MASM. Perfil dos pacientes internados em serviços de pediatria no município do Rio de Janeiro: mudamos? Physis. 2012;22(1):199-214. doi: 10.1590/S010373312012000100011.

16. Moreira MCN, Albernaz LV, de Sá MRC, Correia RF, Tanabe RF. Recomendações para uma linha de cuidados para crianças e adolescentes com condições crônicas complexas de saúde. Cad. Saude Publica. 2017;33(11):1-13. doi: 10.1590/0102-311X00189516.

17. Taquette SR, Villela WV. Balizas do conhecimento: análise das instruções aos autores das revistas brasileiras da área de saúde. Ciênc. Saúde Colet. 2017;22(1):7-13. doi: 10.1590/1413-81232017221.24302016.

18. Gamondi C, Larke P, Payne S. Core competencies in palliative care: an EAPC White Paper on palliative care education - part 1. Eur J Palliat Care. 2013;20(2):86-91 [acesso em 10 de mar de 2020]. Disponível em: http://www.haywardpublishing.co.uk/_year_search_review. aspx?JID $=4 \&$ Year $=2013 \&$ Edition $=474$.

19. Lucchetti G, Granero AL, Bassi RM, Latorraca R, Nassif SAP. Espiritualidade na prática clínica: o que o clínico deve saber. Rev Soc Bras Clín Méd. 2010;8(2):154-8[acesso em 30 de abr de 2020]. Disponível em: https:// pesquisa.bvsalud.org/portal/resource/pt/lil-544002.

20. Ellman MS, Fortin 6 th AH, Putnam A, Bia M. Implementing and evaluating a four-year integrated end-of-life care curriculum for medical students. Teach Learn Med. 2016;28(2):229-39. doi: 10.1080/10401334.2016.1146601.
21. Gibbins J, McCoubrie R, Maher J, Wee B, Forbes K. Recognizing that it is part and parcel of what they do: teaching palliative care to medical students in the UK. Palliat Med. 2010; 24(3):299-305. doi: 10.1177/0269216309356029.

22. Freitas ED. Manifesto pelos cuidados paliativos na graduação em medicina: estudo dirigido da Carta de Praga. Rev Bioét (Impr). 2017;25 (3): 527-35. doi: 10.1590/1983-80422017253209.

23. Murray SA, Firth A, Schneider N, Van den Eynden B, Gomez-Batiste X, Brogaard T, et al. Promoting palliative care in the community: production of the primary palliative care toolkit by the European Association of Palliative Care Taskforce in primary palliative care. Palliat Med. 2015; 29(2):101-11. doi: 10.1177/0269216314545006.

24. Brasil. Resolução no 3, de 20 de junho de 2014. Institui Diretrizes Curriculares Nacionais do Curso de Graduação em Medicina e dá outras providências. Brasília: Ministério da Educação; 2014 [acesso em 16 abr 2020]. Disponível em: http://portal.mec.gov.br/.

25. Pendleton D, SchofieldT,Tate P, HavelockP. A nova consulta: desenvolvendo a comunicação entre médico e paciente. Porto Alegre: Artmed; 2011.

26. Frank VE. Em busca do sentido. Tradução Schlupp WO \& Aveline C. São Leopoldo: Sinodal; Petrópolis: Vozes, 2008.

27. Schulz-Quach C, Wenzel-Meyburg U, Fetz K. Can elearning be used to teach palliative care? - medical students' acceptance, knowledge, and self-estimation of competence in palliative care after elearning. BMC Med Educ. 2018;18(1):82. doi: 10.1186/s12909-018-1186-2.

28. Spalding J, Yardley S. "The nice thing about doctors is that you can sometimes get a day off school": an action research study to bring lived experiences from children, parents and hospice staff into medical students' preparation for practice. BMJ Support Palliat Care. 2016;6(4):45964. doi: 10.1136/bmjspcare-2015-001080.

29. Gibbins J, McCoubrie R, Forbes K. Why are newly qualified doctors unprepared to care for patients at the end of life? Med Educ. 2011;45(4):38999. doi: 10.1111/j.1365-2923.2010.03873.x.

30. Feuerwerker LCM. Mudanças na educação médica \& residência médica no Brasil. São Paulo: Hucitec, Rede Unida; 1998.

31. Brasil. HumanizaSUS: Política Nacional de Humanização. Brasília: Ministério da Saúde; 2003 [acesso em 20 maio 2021]. Disponível em: https://bvsms. saude.gov.br/bvs/publicacoes/humanizaSus.pdf.

32. Conselho Federal de Medicina. Resolução CFM no 1.995/2012. Dispõe sobre as diretivas antecipadas de vontade dos pacientes. Diário Oficial da União; 31 ago 2012. Seção 1, p. 269-70.

33. Silva MLSR. O papel do profissional da atenção primária à saúde em cuidados paliativos. Rev Bras Med Fam Comunidade. 2014 9(30):45-53. doi: $10.5712 /$ rbmfc9(30)718.

34. Souza LSF. Enfrentando o desafio da educação médica. Curitiba: Appris; 2019. 